\title{
UVODNIK
}

\section{KAJ TRANSFORMIRATI? IZOBRAŽEVANJE ODRASLIH, TRAJNOSTNI RAZVOJ IN OKOLJSKA GIBANJA}

V današnji geološki dobi, to je antropocen, so antropogeni procesi - naraščajoči vplivi človeških aktivnosti na Zemljo in atmosfero - ključni dejavnik, ki učinkujejo na planetarno dobrobit (Burns, 2018; Decuypere idr., 2019; Lange, 2018; Wals in Benavost, 2017). Globalno segrevanje Zemlje je posledica povečane vsebnosti ogljikovega dioksida $\left(\mathrm{CO}_{2}\right)$ in drugih toplogrednih plinov, ki se v ozračje sproščajo zaradi človekovih dejavnosti. Z naraščajočo okoljsko krizo se povečuje verjetnost nepovratnih negativnih vplivov tako na živo in neživo naravo (npr. dvig morske gladine, taljenje ledu in ledenikov, zakisljevanje oceanov, izguba biotske raznovrstnosti, poplave, suše) kot ljudi (npr. pomanjkanje pitne vode, lakota, migracije, konflikti) (UN Environment, 2019).

Eden izmed odgovorov na naraščajočo okoljsko krizo, h kateremu so pristopile države pod okriljem Združenih narodov, je leta 2015 sprejeti Pariški sporazum, to je prvi univerzalni in pravno zavezujoči globalni podnebni sporazum, ki ga je do zdaj ratificiralo 189 držav. Njegov temeljni cilj je globalni odziv na nevarnost, ki grozi zaradi spremembe podnebja, in sicer da se dvig povprečne globalne temperature ohrani znatno pod $2^{\circ} \mathrm{C} v$ primerjavi s predindustrijskim obdobjem oziroma da se nadaljujejo prizadevanja, da se dvig temperature omeji na $1,5{ }^{\circ} \mathrm{C}$ v primerjavi s predindustrijskim obdobjem, zavedajoč se, da bi se s tem znatno zmanjšali tveganja in učinki sprememb podnebja (UN, 2016, str. 5). Drug izmed globalnih odzivov prihaja prek mobilizacije več kot šest milijonov mladih, ki so se združili v gibanju Podnebni štrajk pod vodstvom švedske okoljske aktivistke Grete Thunberg, z jasno zahtevo po takojšnjem ukrepanju v boju proti podnebnim spremembam, saj »hiša že gori« (Ollis, 2020; Reid, 2019). Tretjega izmed globalnih odzivov bi lahko prinesla aktualna pandemija covida-19, saj se je, vsaj v prvem valu pandemije, vpliv človeka na okolje, to so onesnaževanje in emisije toplogrednih plinov, opazno zmanjšal (npr. Khan idr., 2021; Rupani idr., 2020), kar navdaja z upanjem, da je okoljske spremembe možno doseči. A ob več kot letu dni trajajoči pandemiji se zdi vse manj verjetno, da nam bo »odločni preskok v obnovljive vire in ekološko vzdržno ekonomijo« (Dolar, 2020, str. 26) dejansko tudi uspel, saj so se različne industrije že prilagodile novi realnosti.

Tudi področje izobraževanja in posebej izobraževanja odraslih, od globalne do lokalne ravni, ni ostalo imuno za vprašanja, ki jih sprožajo podnebne spremembe in globalna 
okoljska kriza. Nasprotno. Mobilizacija izobraževanja za potrebe reševanja okoljskih izzivov ni nič novega, saj tovrstna prizadevanja opazimo že konec 19. stoletja v izobraževanju za ohranjanje narave, v 60. letih 20. stoletja se pojavi okoljsko izobraževanje/ okoljsko izobraževanje odraslih, o trajnostnem izobraževanju se govori od vrha o okolju v Riu leta 1992 dalje, danes pa sta v ospredju okoljsko in trajnostno izobraževanje ter izobraževanje za trajnostni razvoj (Lange, 2018; Wals in Benavot, 2017). Izobraževanje za trajnostni razvoj je danes na globalni ravni spodbujeno predvsem na podlagi ciljev trajnostnega razvoja, ki so jih sprejeli Združeni narodi, da bi ustvarili pravičnejšo globalno družbo. Prva agenda ciljev trajnostnega razvoja, to je Millennium Development Goals and the Education for All, je bila sprejeta leta 2000, vključevala je osem ciljev, ki naj bi jih dosegli do leta 2015. Druga, trenutno aktualna agenda, to je Transforming Our World: The 2030 Agenda for Sustainable Development, pa je bila sprejeta septembra 2015 in vključuje 17 ambicioznih ciljev, ki naslavljajo tri prevladujoče razsežnosti trajnosti: ekonomsko, družbeno in okoljsko. Te cilje trajnostnega razvoja (CTR) naj bi dosegli do leta 2030, pri tem pa naj bi pomembno vlogo imelo prav izobraževanje, saj je CTR 4 - to je zagotavljanje vključujočega in pravičnega kakovostnega izobraževanja ter spodbujanje vseživljenjskega učenja za vse - bistven za dosego trajnosti (Benavot, 2017; Boeren, 2019; Burt, 2019; Komatsu idr., 2020; Orlović Lovren in Popović, 2018; Schreiber-Barsch in Mauch, 2019).

A CTR niso neproblematični, saj temeljijo na dveh v osnovi nezdružljivih filozofijah, to sta zavezanost kapitalizma k nadaljnji gospodarski rasti na eni strani ter spoštovanje planetarnih omejitev in transformacija sveta na drugi (Wulff, 2020). Zdi se, da podobni logiki sledi tudi Evropski zeleni dogovor (Evropska komisija, 2019) - ta naj bi pomagal narediti Evropo podnebno nevtralno do leta 2050 -, ki pri preoblikovanju gospodarstva stavi na spremembe, inovacije in rast (globalno konkurenčnost, tranzicijo v zelena delovna mesta in digitalizacijo). V nasprotju $\mathrm{z}$ »zelenim kapitalizmom « pa se npr. zagovorniki koncepta odrasti (npr. Liegey in Nelson, 2020; Plut, 2019; Živčič, 2015), ki se je začel razvijati že v 70. letih 20. stoletja, svojo celostno podobo pa pridobil na prvi konferenci o odrasti v Parizu leta 2008, raje zavzemajo za ohranjanje kakovostnega življenja ob hkratnem zmanjševanju porabe materialov, surovin in mnogoterih pritiskov na okolje $\mathrm{v}$ okviru planetarnih danosti ter, v nasprotju z modelom gospodarstva, temelječem na rasti, $\mathrm{z}$ odrastjo ponujajo družbeno in ekosistemsko alternativo tako liberalnemu kot zelenemu kapitalizmu. Skratka, razbliniti je treba iluzijo, da je lahko gospodarski svetovni red, ki temelji na permanentni rasti in maksimiranju dobička, vzdržen za okolje, in si zastaviti vprašanje, kot so to storili Komatsu idr. (2020), kako današnje izobraževanje prispeva k ohranjanju in reproduciranju te iluzije.

Okoljsko in trajnostno izobraževanje lahko poteka v različnih kontekstih (Lange, 2018): tako v sistemu formalnega izobraževanja kakor tudi kot neformalno izobraževanje in informalno/priložnostno učenje $\mathrm{v}$ civilni družbi - v nevladnih organizacijah, prek družbenih gibanj in socialnih medijev -, na delovnem mestu (gl. Lemmetty in Collin, 2020) ter prek strokovnih združenj in sindikatov (gl. Clarke in Lipsig-Mummé, 2020). 
V osnovi lahko razlikujemo med dvema pristopoma do okoljskega in trajnostnega izobraževanja. Prvi se osredotoča na izobraževanje, ki si prizadeva oblikovati določeno okoljsko znanje, spretnosti, naravnanosti, tehnološke rešitve ipd., ki lahko vodijo do sprememb v okoljskem vedenju in ravnanju ljudi (npr. recikliranje, ohranjanje vode, zmanjšanje emisij toplogrednih plinov), a ohranja »status quo« glede družbenega, ekonomskega in političnega sistema. Drugi se osredotoča na izobraževanje, katerega cilj je oblikovati refleksivnega in odgovornega državljana, ki je zmožen samostojnega odločanja in ravnanja v skladu z načeli in vrednotami trajnostnega razvoja (npr. učenje o naravi odnosov med ljudmi in planetom, ki vodi k spopadanju s temeljnimi vzroki uničujočega upravljanja okolja) ter si prizadeva za spremembo obstoječih odnosov in struktur moči. Ta dva pristopa avtorji opisujejo z različnimi opredelitvami: kot »instrumentalni« in »emancipatorni« pristop (Wals in Benavot, 2017), kot »konservativni « in »radikalni « pristop (Griswold, 2017) ali kot »plitki« in »globoki« ekološki model izobraževanja (Misiaszek, 2012).

Raziskave na eni strani kažejo, da ima izobraževanje pomembno vlogo pri obravnavanju in reševanju okoljskih izzivov, saj vodi do večje občutljivosti za okoljska vprašanja, kakor tudi do prookoljskega političnega ravnanja (npr. do podpore okoljskim politikam, glasovanja za zelene stranke, udeležbe v okoljskem aktivizmu), osebne transformacije (npr. spremembe življenjskega sloga), pa tudi širših prookoljskih družbenih sprememb (gl. npr. Cordero idr., 2020; Gal in Gan, 2020; Moyer in Sinclair, 2020; Seddon, 2016; Wals in Benavot, 2017). Na drugi strani kritiki poudarjajo, da četudi ima izobraževanje pomembno vlogo pri oblikovanju posameznikovega dojemanja klimatskih sprememb, slednje ne vodi nujno do sprememb v posameznikovem ravnanju, da naloga izobraževanja ni reševanje okoljsko-družbenih problemov - v CTR je izobraževanje zastavljeno instrumentalno (prim. Mikulec, 2018), vedno v službi napredka pri doseganju drugih CTR - ter da agenda izobraževanja za trajnostni razvoj zgolj podpira obstoječi neoliberalni kapitalistični sistem ter ne spreminja odnosov moči in struktur zatiranja v družbi (gl. npr. Elfert, 2019; Gadotti, 2008; Ireland, 2018; Komatsu idr., 2020; Reid, 2019; Zaval in Cornwell, 2017).

Zdi se, da je v osrčju okoljskega in trajnostnega izobraževanja transformacija (Burns, 2018; Clover idr., 2013; Elfert, 2019; Misiaszek, 2016; Schreiber-Barsch in Mauch, 2019; Walters, 2018), pri čemer ostaja odprto vprašanje, kdo, kaj in v kakšnem obsegu naj bi se transformiral. Eno izmed ključnih vprašanj okoljskega in trajnostnega izobraževanja se torej glasi: Kaj je treba transformirati in kaj ohraniti (prim. Wals idr., 2017)?

Pri raziskovanju tega vprašanja se lahko opremo na teorije transformativnega učenja, ki imajo svojo bogato tradicijo prav na področju izobraževanja odraslih. Kot ugotavlja Lange (2019), lahko razlikujemo med tremi pristopi transformativnega učenja, ki spodbujajo (1) individualno spremembo na mikroravni, (2) transpersonalno in organizacijsko spremembo na mezoravni ter (3) družbeno spremembo na makroravni. Prvi pristop izhaja iz teorije transformativnega učenja Jacka Mezirowa (1991) in se nanaša na spremembo perspektive, to je na sistem nekritično prevzetih prepričanj, da bi postali bolj inkluzivni, odprti, emocionalno zmožni spremembe in reflektivni, da bi ustvarili prepričanja in mnenja, ki so bolj resnična in upravičena. Poudarek je na spremembi posameznika - spremembi njegovega 
svetovnega nazora, vedenja, epistemologije in ontologije (Hoggan, 2016) -, ki temelji na kogniciji in racionalnosti posameznika oz. na zmožnosti kritične refleksije, brez katere tudi ni transformativnega učenja (Fleming idr., 2019). Drugi pristop izhaja iz analitične globinske psihologije Carla Gustava Junga in organizacijske transformativne teorije, pri čemer se transformacija nanaša na temeljno spremembo posameznikove osebnosti, ki vodi k celovitosti sebstva. Je transpersonalna, saj spodbuja povezanost posameznikovega sebstva z ostalo živo in neživo naravo. Ta teorija transformativnega učenja sega onkraj racionalnosti v domeno čustev, simbolov in imaginacije. Tretji pristop izhaja iz del Paula Freireja (2005) in se osredotoča na družbene spremembe na makroravni. Transformativno učenje tukaj poteka kot ozaveščanje (conscientizacão), to je proces, v katerem učeči se razvijajo zavedanje o ekonomskih, tehnoloških, političnih, kulturnih strukturah v družbi, ki prispevajo k neenakosti in zatiranju, pri čemer je bistveno, da učeči se reflektirajo svoj svet in ga tako tudi spremenijo, kar prinese osvoboditev tako na osebni kot družbeni ravni. Ozaveščanje torej poteka prek »praxis«, z združitvijo akcije (delovanja) in refleksije (mišljenja). Za tovrstno izobraževanje je prav tako ključno, da poleg kritike različnih oblik zatiranja gradi na viziji, upanju in utopiji o možnem boljšem svetu, s čimer se izogne fatalistični neoliberalni agendi, ki zanika možnosti drugačnega sveta (Ireland, 2018). Okoljsko in trajnostno izobraževanje, ki ga je navdihnil Freire, se danes razvija v gibanju za ekopedagogiko predvsem v Latinski Ameriki. To izobraževanje si prizadeva za spremembo obstoječih človeških, družbenih in okoljskih odnosov ter spodbuja kolektivno ekopismenost in planetarno državljanstvo v nasprotju z neoliberalno globalizacijo in imperializmom (Gadotti, 2008, 2011; Kahn, 2010; Misiaszek, 2012, 2016). Sem sodijo tudi okoljsko naravnana družbena gibanja po vsem svetu, ki si prek kolektivne akcije in z generiranjem novega znanja prizadevajo za družbeno-okoljske spremembe in okoljsko pravičnost (npr. Burt, 2019; Clover idr., 2013; Kahn, 2010; Ollis, 2020; Walters in von Kotze, 2019).

Pri raziskovanju trajnostnega razvoja in transformativnega učenja se pojavlja tudi četrti pristop, to je transformativno trajnostno izobraževanje, ki stavi na odnosno razumevanje trajnostnega razvoja - ta v ospredje postavlja način bivanja in védenja, v katerem smo vsi/vse v medsebojnem odnosu in medsebojno povezani - ter prevpraševanje temeljnih ontoloških, epistemoloških in kozmoloških korenin naših družb (Burns, 2018; Lange, 2018, 2019).

V tokratni tematski številki Andragoških spoznanj, ki zajema šest tematskih člankov, avtorice in avtorji razmišljajo o izzivih trajnostnega razvoja, okoljskega in trajnostnega izobraževanja, okoljskih gibanjih, transformaciji in izobraževanju odraslih z vidika različnih teoretskih perspektiv in metodoloških pristopov.

Avtorice Elizabeth A. Lange, Joy Kcenia Polanco O'Neil in Katie E. Ross v članku Izobraževati med veliko transformacijo: odnosnost in transformativno trajnostno izobraževanje razpravljajo o tem, kako so posamezniki in družbe, potopljeni v ločevalno paradigmo, temelječo na tehnoloških industrijskih vrednotah zahodne evrocentrične kulture, nehote uničujoči, ker ne zaznajo relacijske narave našega univerzuma, pri čemer pokažejo, da obstoječi procesi učenja in izobraževanja, vključno s trajnostnim izobraževanjem, še naprej reproducirajo ločevalno paradigmo. V nasprotju s slednjo avtorice zagovarjajo odnosno 
paradigmo, to je odnosne načine spoznavanja in bivanja, ki terjajo transformacijo zahodnih prepričanj o kozmologiji, načinih bivanja, etiki in epistemologiji, ter tako nakažejo implikacije morebitne svetovnonazorske transformacije za izobraževalce in izobraževalne procese, zlasti v okviru transformativnega trajnostnega izobraževanja.

Shirley Walters in Astrid von Kotze v članku Razlogi za ekofeministično ljudsko izobraževanje v času COVID-19 prav tako pišeta o nujnosti radikalne transformacije sveta, izhajajoč iz teoretskega okvira ekofeminizma, ki obravnava vprašanja patriarhata, kapitalizma in degradacije okolja. Na podlagi kritične analize zdravstvenega tečaja za ženske v Republiki Južni Afriki, ki je avtoricama služil kot študija primera ljudskega izobraževanja (popular education) v času covida-19, razpravljata o tem, kako bi se moral spremeniti kurikulum, da bi bilo pridobljeno znanje za udeležence resnično koristno za transformativno spremembo. Ob identificiranih principih ekofeminizma za izobraževalce avtorici skleneta, da so elementi, ki se neposredno nanašajo na življenje udeležencev (npr. prehranska varnost, voda), tisti, ki lahko izzovejo prevladujoče dojemanje narave kot »stvari« ter vzpostavijo dojemanje narave kot kompleksnega in medsebojno povezanega ekosistema.

Lauren Spring in Darlene Clover v članku Muzeji, socioekološko razmišljanje in aktivistične pedagogike domišljije preučujeta vlogo muzejev v trenutni okoljski krizi kot tistih institucij, ki so zelo pomembne, a v literaturi o okoljski krizi vse prevečkrat prezrte, čeprav lahko pomembno pripomorejo $\mathrm{k}$ reševanju vprašanj okoljske pravičnosti in okoljskega izobraževanja odraslih ter prispevajo k vseživljenjskemu učenju. Avtorici na eni strani pokažeta, kako so se in se še danes muzeji ukvarjajo s prakso »monokulturnega« (netrajnostnega) mišljenja, ki ohranja patriarhalno kapitalistični neoliberalni ustroj in vizijo binarne delitve moči, prevlade in nadzora med človeškim in nečloveškim, a na drugi strani opozarjata, da vse več muzejev danes spreminja svoje pristope. Na podlagi analize primerov iz Kanade avtorici pokažeta, da muzeji s svojim intencionalnim ravnanjem pri reševanju okoljskih vprašanj lahko ustvarjajo »opozicijske poglede«, ki delujejo kot vzgojni prostori odpora za doseganje družbeno-okoljskih sprememb.

Siniša Kušić in Renata Hasel v članku Kompetence učiteljev za implementacijo trajnostnega razvoja v okviru izobraževanja odraslih izpostavita pomen učiteljevih kompetenc za trajnostni razvoj v izobraževanju odraslih ter v empirični študiji, opravljeni na vzorcu učiteljev, ki delajo v institucijah izobraževanja odraslih na Hrvaškem, preučujeta, ali imajo učitelji ustrezne kompetence za implementacijo trajnostnega razvoja v proces poučevanja. Avtorja ugotavljata, da učitelji sicer kažejo pozitivno naravnanost do trajnostnega razvoja, a imajo slabše znanje o konceptih trajnostnega razvoja ter le delno obvladajo potrebne kompetence za implementacijo trajnostnega razvoja v izobraževalni proces pri poučevanju odraslih.

Tadej Košmerl v članku Od kolonialnega učenja do izobraževanja za trajnostni razvoj: pregled izbranih konceptov izobraževanja o globalni soodvisnosti analizira nekatere temeljne koncepte medvladnih organizacij, predvsem UNESCO in OECD, na področju izobraževanja, kot so globalno izobraževanje, globalno učenje, izobraževanje za globalno državljanstvo, izobraževanje za razvoj in izobraževanje za trajnostni razvoj. Ob tem 
ugotavlja, da tovrstni izobraževalni koncepti na eni strani povzročajo vrsto terminoloških in konceptualnih nejasnosti, na drugi pa se v zadnjem desetletju v vseh bolj poudarjajo okoljski izzivi in trajnostni razvoj, organizacije, ki uporabljajo in razvijajo posamezne koncepte, pa jih zdaj postavljajo v kontekst ciljev trajnostnega razvoja. Ob slednjih pa avtor izpostavlja, da ti niso radikalna alternativa sistemom, ki so nas pripeljali do trenutne okoljske krize, ampak prej poskus njihove prilagoditve na način, ki naj bi omogočil (oz. celo pospešil) nadaljnji gospodarski razvoj.

Nevenka Bogataj v članku Vzgoja in izobraževanje za trajnostni razvoj širi razumevanje javnega interesa v izobraževanju odraslih razpravlja o potrebi po vključitvi okoljskih tem v izobraževanje odraslih v Sloveniji na način, da vzgoja in izobraževanje za trajnostni razvoj postaneta del celovitejše sistemske zasnove, javnega interesa politike ter del širših strateških prioritet države. Avtorica analizira tri vidike izobraževanja odraslih za trajnostni razvoj - sistemsko podporo, raziskovalne podlage in izobraževalno ponudbo - ter ugotavlja, da izobraževanje odraslih za trajnostni razvoj vsebuje potencial za rekonceptualizacijo zasnove izobraževanja odraslih iz ekskluzivne in na primanjkljajih utemeljene paradigme v vključujočo in na potencialih ter prednostih utemeljeno paradigmo.

Poleg tematskih člankov pričujoča številka vključuje tudi dva odprta članka, poročilo, dve knjižni recenziji ter dva spominska zapisa.

Urška Gačnik in Jernej Kovač v članku Proučevanje mnenj o izobraževanju starejših oseb na kulturno-umetniškem področju na vzorcu starejših, ki bivajo v domovih za starejše v Mariboru, ugotavljata, da se velika večina starejših oseb zaveda pomena izobraževanja na kulturno-umetniškem področju ter da moški in osebe z višjo stopnjo pridobljene izobrazbe pripisujejo izobraževanju na kulturno-umetniškem področju večji pomen. V članku Učenje na delovnem mestu v kontekstu visokošolskega praktičnega usposabljanja: primer turizma Marija Rok preučuje učenje na delovnem mestu na primeru praktičnega usposabljanja študentov v visokošolskih programih na področju turizma v Sloveniji ter na podlagi opravljene analize obstoječih sistemov razvije nov model praktičnega usposabljanja v turističnem sektorju z identifikacijo ključnih indikatorjev kakovosti tovrstnega sistema.

V poročilu Uporabnost spletne strani Teacher's Climate Guide za samoizobraževanje andragogov in načrtovanje izobraževanja odraslih o okoljski problematiki Andraž Fink poroča o vsebinah spletne platforme Teacher's Climate Guide, ki lahko pomeni kakovosten vir za razvoj različnih oblik izobraževanja odraslih, povezanih z razumevanjem okoljske problematike. Sledita dve recenziji knjig: Environmental and Animal Abuse Denial: Averting Our Gaze, ki jo je pripravil Tadej Košmerl, in Starost II: Biti v svetu, ki jo je pripravila Dušana Findeisen. Številko zaključujeta zapisa Sonje Kump in Zorana Jelenca v spomin Sabini Jelenc Krašovec - urednici Andragoških spoznanj, profesorici Oddelka za pedagogiko in andragogiko, raziskovalki izobraževanja odraslih, dragi kolegici, ki jo bomo ohranili v naših srcih in spominih. 


\section{LITERATURA}

Benavot, A. (2017). Education for people, prosperity and planet: Can we meet the sustainability challenges? European Journal of Education, 52(4), 399-403.

Boeren, E. (2019). Understanding Sustainable Development Goal (SDG) 4 on "quality education" from micro, meso and macro perspectives. International Review of Education, 65(2), 277-294.

Burns, H. (2018). Thematic Analysis: Transformative Sustainability Education. Journal of Transformative Education, 16(4), 277-279.

Burt, J. (2019). Research for the People, by the People: The Political Practice of Cognitive Justice and Transformative Learning in Environmental Social Movements. Sustainability, 11(20), 1-21.

Clarke, L. in Lipsig-Mummé, C. (2020). Future conditional: From just transition to radical transformation? European Journal of Industrial Relations, 26(4) 351-366.

Clover, D. E., Jayme, B. d. O., Hall, B. L. in Follen, S. (2013). The Nature of Transformation. Environmental Adult Education. Sense Publishers.

Cordero, E. C., Centeno, D. in Todd, A. M. (2020). The role of climate change education on individual lifetime carbon emissions. PLoS ONE, 15(2), 1-23.

Decuypere, M., Hoet, H. in Vandenabeele, J. (2019). Learning to Navigate (in) the Anthropocene. Sustainability, 11(2), 547.

Dolar, M. (2020, maj). Denar ali življenje? Mladina, posebna izdaja, 22-27.

Elfert, M. (2019). Lifelong learning in Sustainable Development Goal 4: What does it mean for UNESCO's rights-based approach to adult learning and education? International Review of Education, 65(2), 537-556.

Evropska komisija. (2019). Evropski zeleni dogovor. https://eur-lex.europa.eu/resource.html?uri=cellar:b828d165-1c22-11ea-8c1f-01aa75ed71a1.0015.02/DO C_1\&format=PDF

Fleming, T., Kokkos, A. in Finnegan, F. (2019). European Perspectives on Transformation Theory. Palgrave Macmillan.

Freire, P. (2005). Pedagogy of the Oppressed. Continuum.

Gadotti, M. (2008). Education for Sustainability: A critical contribution to the Decade of Education for Sustainable Development. Green Theory \& Praxis Journal, 4(1), 15-64.

Gadotti, M. (2011). Adult education as a human right: The Latin American context and the ecopedagogic perspective. International Review of Education, 75(1-2), 9-25.

Gal, A. in Gan, D. (2020). Transformative Sustainability Education in Higher Education: Activating Environmental Understanding and Active Citizenship Among Professional Studies Learners. Journal of Transformative Education, 18(4), 271-292.

Griswold, W. (2017). Sustainability, Ecojustice, and Adult Education. New Directions for Adult \& Continuing Education, 153, 7-15.

Hoggan, C. D. (2016). Transformative Learning as a Metatheory: Definition, Criteria, and Typology. Adult Education Quarterly, 66(1), 57-75.

Ireland, T. D. (2018). The Relevance of Freire for the Post-2015 International Debate on Development and Education and the Role of Popular Education. V A. Melling in R. Pilkington (ur.), Paulo Freire and Transformative Education: Changing Lives and Transforming Communities (str. 15-28). Palgrave Macmillan.

Kahn, R. (2010). Critical Pedagogy, Ecoliteracy, \& Planetary Crisis: The Ecopedagogy movement. Peter Lang.

Khan, I., Shah, D. in Shah, S. S. (2021). COVID-19 pandemic and its positive impacts on environment: an updated review. International Journal of Environmental Science and Technology, 18(2), 521-530. 
Komatsu, H., Rappleye, J. in Silova, I. (2020). Will Education Post-2015 Move Us toward Environmental Sustainability? V A. Wulff (ur.), Grading Goal Four: Tensions, Threats, and Opportunities in the Sustainable Development Goal on Quality Education (str. 297-321). Brill.

Lange, E. (2018). Transformative Sustainability Education: From Sustainababble to a Civilization Leap. V M. Milana, S. Webb, J. Holford, R. Waller in P. Jarvis (ur.), The Palgrave International Handbook on Adult and Lifelong Education and Learning (str. 397-420). Palgrave Macmillan.

Lange, E. (2019). Transformative Learning for Sustainability. V W. Leal Filho (ur.), Encyclopedia of Sustainability in Higher Education. Springer.

Lemmetty, S. in Collin, K. (2020). Throwaway knowledge, useful skills or a source for wellbeing? Outlining sustainability of workplace learning situations. International Journal of Lifelong Education, 39(5-6), 478-494.

Liegey, V. in Nelson, A. (2020). Exploring Degrowth: A Critical Guide. Pluto Press.

Mezirow, J. (1991). Transformative dimensions of adult learning. Jossey-Bass.

Mikulec, B. (2018). Normative presumptions of the European Union's adult education policy. Studies in the education of adults, 50(2), 133-151.

Misiaszek, G. (2012). Transformative Environmental Education Within Social Justice Models: Lessons from Comparing Adult Ecopedagogy Within North and South America. V D. N. Aspin, J. Chapman, K. Evans in R. Bagnall (ur.), Second International Handbook of Lifelong Learning (str. 423-440). Springer.

Misiaszek, G. (2016). Ecopedagogy as an element of citizenship education: The dialectic of global/local spheres of citizenship and critical environmental pedagogies. International Review of Education, 62(5), 587-607.

Moyer, J. M. in Sinclair, A. J. (2020). Learning for Sustainability: Considering Pathways to Transformation. Adult Education Quarterly, 70(4), 340-359.

Ollis, T. A. (2020). Adult learning and circumstantial activism in the coal seam gas protests: Informal and incidental learning in an environmental justice movement. Studies in the Education of Adults, 52(2), 215-231.

Orlović Lovren, V. in Popović, K. (2018). Lifelong Learning for Sustainable Development-Is Adult Education Left Behind? V W. Leal Filho, M. Mifsud in P. Pace (ur.), Handbook of Lifelong Learning for Sustainable Development (str. 1-18). Springer.

Plut, D. (10. 8. 2019). Odrast - ekosistemski odgovor na okoljsko-podnebno krizo. Sobotna priloga Dela, 20-22.

Reid, A. (2019). Climate change education and research: possibilities and potentials versus problems and perils? Environmental Education Research, 25(6), 767-790.

Rupani, P. F., Nilashi, M., Abumalloh, R. A., Asadi, S., Samad, S. in Wang, S. (2020). Coronavirus pandemic (COVID-19) and its natural environmental impacts. International Journal of Environmental Science and Technology, 17(11), 4655-4666.

Schreiber-Barsch, S. in Mauch, W. (2019). Adult learning and education as a response to global challenges: Fostering agents of social transformation and sustainability. International Review of Education, 65(4), 515-536.

Seddon, T. (2016). Sustainable development and social learning: Re-contextualising the space of orientation. International Review of Education, 62(5), 563-586.

UN. (2016). Paris Agreement. https://eur-lex.europa.eu/legal-content/EN/TXT/PDF/?uri=CELEX:22016A1019(01)\&from $=\mathrm{EN}$

UN Environment. (2019). Global Environment Outlook - GEO-6: Healthy Planet, Healthy People. Cambridge University Press. 
Wals, A. E. J. in Benavot, A. (2017). Can we meet the sustainability challenges? The role of education and lifelong learning. European Journal of Education, 52(4), 404-413.

Wals, A. E. J., Mochizuki, Y. in Leicht, A. (2017). Critical case-studies of non-formal and community learning for sustainable development. International Review of Education, 63(6), 783-792.

Walters, S. (2018). 'The drought is my teacher': Adult learning and education in times of climate crisis. Journal of Vocational, Adult and Continuing Education and Training, 1(1), 146-162.

Walters, S. in von Kotze, A. (2019). "If you can't measure it, it doesn't exist"? Popular education in the shadows of global reporting on adult learning and education. Studies in the Education of Adults, $51(1), 3-14$.

Wulff, A. (2020). Introduction: Bringing out the Tensions, Challenges, and Opportunities within Sustainable Development Goal 4. V A. Wulff (ur.), Grading Goal Four: Tensions, Threats, and Opportunities in the Sustainable Development Goal on Quality Education (str. 1-27). Brill.

Zaval, L. in Cornwell, J. F. M. (2017). Effective education and communication strategies to promote environmental engagement. European Journal of Education, 52(4), 477-486.

Živčič, L. (2015). Odgovor na družbene, ekonomske in okoljske meje rasti: predstavitev koncepta odrast (degrowth) ter njegova raba v praksi. Časopis za kritiko znanosti, 43(262), 151-168. 